INDONESIAN HEALTH ISSUE

\title{
Hubungan Pendapatan Keluarga dan Pola Makan dengan Kejadian Underweight Pada Balita
}

\author{
Yizri Novfrida ${ }^{1}$, Erna Juliana Simatupang ${ }^{2}$, Moudy E U Djami ${ }^{3}$, Rangga Pusmaika ${ }^{4}$, \\ lis Sumiyati ${ }^{5}$ \\ ${ }^{1-5}$ Akbid Bina Husada Tangerang \\ Email korespondensi: mrsnovfrida@gmail.com \\ No HP: 081315659464
}

\begin{tabular}{l}
\hline ARTICLE INFO \\
Article History: \\
Received : \\
12 Januari 2022 \\
Accepted : \\
14 Februari 2022 \\
Published : \\
16 Februari 2022 \\
\hline
\end{tabular}

Kata Kunci:

Pendapatan;Pola

Makan; Underweight

Keywords:

Family Income;Food

Consumption;

Underweigt

\begin{abstract}
ABSTRAK
Latar Belakang: Status gizi underweight pada balita masih menjadi permasalahan serius di Indonesia. Secara Global, pada tahun 2018 terdapat $10,2 \%$ balita underweight di Indonesia. Tujuan: Untuk mengetahui hubungan pendapatan keluarga dan pola makan anak dengan kejadian underweight pada balita 12-59 bulan di Desa Taban. Metode: Desain penelitian case control dengan sampel 110 responden (55 kasus dan 55 kontrol). Pemilihan sampel dengan systematic random sampling, analisis menggunakan uji chi square, dengan convident interval (Cl) 95\%. Hasil: Hasil penelitian diketahui terdapat hubungan antara pendapatan keluarga $(0,000$, OR 4,997$)$, pola makan $(0,005$, OR 4,865$)$ dengan kejadian underweight. Kesimpulan: Pemerintah mendorong masyarakat untuk meningkatkan income perkapita masyarakat di desa Taban melalui upaya pertanian, peningkatan usaha peternakan dan atau meningkatkan kondisi desa pada peningkatan usaha home industry sehingga dapat mengungkit daya beli bahan makanan bergizi dan konsumsi pangan yang berkualitas.

ABSTRACT

Background: The nutritional status of underweight children under five years of age remains a serious problem in Indonesia. Globally, in 2018 there were $10.2 \%$ underweight children in Indonesia. Purpose: to determine the relationship between family income and food consumption pattern with underweight children 12-59 months old in Taban village. Methods: Case control research design with 110 respondents (55 cases and 55 control). Selection of samples by systematic random sampling, analysis using the chi square test, with 95\% convident interval $(\mathrm{Cl})$. Results: There is no relationship between sanitation with underweight (0.332). It can be concluded that the variables of family income, and food consumption pattern are the factors causing underweight. Conclusion: The government encourages the community to increase the income per capita of the people in Taban village through agricultural efforts, increasing livestock business and or improving village conditions by increasing home industry businesses so that they can increase the purchasing power of nutritious food and quality food consumption.
\end{abstract}




\section{PENDAHULUAN}

Pemenuhan kebutuhan nutrisi yang baik sangat penting untuk membantu anak-anak bertahan hidup, tumbuh sehat, terhindar dari penyakit, dan untuk menyempurnakan perkembangan kognitif, emosional dan afektifnya. Kondisi gizi kurang menyumbang 35\% dari kematian pada balita. Kurangnya kebutuhan nutrisi pada balita menyebabkan 1 dari 4 balita mengalami malnutrisi (Unicef, 2018).

Malnutrisi selama periode ini dapat menyebabkan dampak serius pada pertumbuhan dan perkembangan pada anak-anak, yang lebih sulit untuk dipulihkan Ketika diberikan intervensi yang terlambat (WHO, 2009). Anak-anak dengan malnutrisi akut berat memiliki 5 sampai 20 kali risiko kematian yang lebih tinggi dibandingkan dengan anak yang gizi baik. Banyak faktor yang diduga mempengaruhi status gizi anak. Studi sebelumnya telah menunjukkan bahwa determinan penting kejadian gizi buruk pada anak adalah praktik pemberian makan bayi, status imunisasi, pemantauan pertumbuhan, berat lahir, dan pendidikan ibu. Praktik pemberian makan yang buruk dan penyakit disebabkan oleh kerawanan pangan, perawatan ibu dan anak yang tidak memadai, serta pelayanan kesehatan dan lingkungan yang buruk. Faktor-faktor ini menyebabkan kerugian yang terukur efek pada fungsi tubuh dan hasil klinis (WHO \& Bank, 2019).

Meskipun ada intervensi untuk mengatasi kekurangan gizi anak, namun saat ini masih menjadi masalah kesehatan masyarakat global yang utama. Malnutrisi anak di bawah lima tahun merupakan penyebab utama hampir setengah $(45 \%)$ kematian anak, khususnya di komunitas sosial ekonomi rendah di negara berkembang. Secara global pada tahun 2018, di Indonesia terdapat proporsi balita underweight 10,2\%. (Watson et al., 2019; WHO, 2020).

Hasil penelitian Samino (2020), diketahui terdapat hubungan antara pola konsumsi makan $(0,001$, OR 6,46$)$, penyakit infeksi $(0,001$, OR 6,03$)$, pola asuh $(0,002$, OR 5,07$)$, menimbang berat badan $(0,029$, OR 2,662$)$ dengan kejadian underweight pada balita. (Samino et al., 2020). Underweight timbul oleh karena kesenjangan yang terjadi akibat keadaan gizi yang diharapkan tidak sesuai dengan kenyataan. Penyebab underweight adalah asupan zat gizi dalam tubuh. Dua faktor yang mempengaruhi pemanfaatan zat gizi oleh tubuh, yaitu primer dan sekunder. Faktor primer adalah kurangnya ketersediaan pangan dalam keluarga, sehingga keluarga tidak memperoleh makanan yang cukup untuk dikonsumsi anggota keluarga; kemiskinan, ketidakmampuan keluarga untuk menyediakan makanan yang cukup bagi anggota keluarganya; pengetahuan yang rendah tentang pentingnya zat gizi untuk kesehatan; kebiasaan makan yang salah, termasuk adanya pantangan pada makanan tertentu (Thamaria, 2017).

Mengingat masalah underweight pada balita merupakan perioritas program pemerintah dan merupakan masalah yang belum teratasi sampai saat ini, Kabupaten Tangerang juga memiliki prevelansi kejadian underweight yang masih tinggi khususnya Kecamatan Jambe yang merupakan kecamatan yang diprioritaskan karena merupakan lokus kejadian underweight di Kabupaten Tangerang. Oleh karenanya penting dilakukan penelitian tentang determinan malnutrisi pada balita di Desa Taban, Jambe Tahun 2021. 


\section{METODE PENELITIAN}

Jenis penelitian kuantitatif dengan rancangan case control, bertempat di Desa Taban wilayah kerja Puskesmas Jambe yang dilaksanakan bulan Agustus 2020. Populasi adalah ibu yang memiliki balita 12-59 bulan sebanyak 324 balita. Sampel diambil dengan systematic random sampling pada balita dengan berat badan dibandingkan umur <-2SD untuk kelompok kasus dan $\geq-2 S D$ untuk kelompok kontrol, sehingga sampel 55 responden kelompok kasus dan 55 kontrol (1:1). Pengumpulan Data menggunakan data primer menggunakan kuisioner dan penimbangan berat badan secara langsung. Analisis menggunakan uji chi-square dengan derajat kepercayaan $(\mathrm{Cl})$ 95\%.

\section{HASIL PENELITIAN}

\section{a. Analisis Univariat}

Tabel.1. Distribusi frekuensi karakteristik responden

\begin{tabular}{|c|c|c|}
\hline Variabel & $f$ & $\%$ \\
\hline \multicolumn{3}{|l|}{ Jenis Kelamin } \\
\hline Perempuan & 53 & 48,2 \\
\hline Laki-laki & 57 & 51,8 \\
\hline \multicolumn{3}{|l|}{ Pendidikan Ibu } \\
\hline Tinggi (SMA-PT) & 22 & 20,0 \\
\hline Rendah (SD-SMP) & 88 & 80,0 \\
\hline \multicolumn{3}{|l|}{ Pekerjaan Ibu } \\
\hline Bekerja & 20 & 18,2 \\
\hline IRT & 90 & 81,8 \\
\hline \multicolumn{3}{|l|}{ Pendapatan Keluarga } \\
\hline Tinggi $(\geq 3.000 .000)$ & 55 & 50,0 \\
\hline Rendah $(<3.000 .000)$ & 55 & 50,0 \\
\hline \multicolumn{3}{|l|}{ Riwayat Pemberian ASI } \\
\hline ASI Ekslusif & 83 & 75,5 \\
\hline Tidak ASI Ekslusif & 27 & 24,5 \\
\hline \multicolumn{3}{|l|}{ Riwayat Diare } \\
\hline Tidak & 73 & 66,4 \\
\hline $\mathrm{Ya}$ & 37 & 33,6 \\
\hline \multicolumn{3}{|l|}{ Pola Makan } \\
\hline Baik & 87 & 79,1 \\
\hline Kurang & 23 & 20,9 \\
\hline Total & 110 & 100 \\
\hline
\end{tabular}

Berdasarkan tabel diatas dapat diketahui mayoritas balita berjenis kelamin laki-laki $(51,8 \%)$, mayoritas ibu berpendidikan rendah $(80,0 \%)$, mayoritas ibu sebagai ibu rumah tangga $(81,8 \%)$, pendapatan keluarga tinggi dan rendah memiliki proporsi yang sama (50,0\%), mayoritas balita diberikan ASI Ekslusif $(75,5$ $\%)$, dan mayoritas balita tidak memiliki riwayat diare $(66,4 \%)$, dan mayoritas balita memiliki pola makan baik setiap harinya $(79,1 \%)$. 
b. Analisis Bivariat

Tabel 2. Hubungan Pendapatan Keluarga dan Pola Makan dengan

Kejadian Underweight

\begin{tabular}{|c|c|c|c|c|c|c|}
\hline \multirow[t]{2}{*}{ Variabel } & \multicolumn{4}{|c|}{$\begin{array}{l}\text { Status Gizi Balita } \\
\end{array}$} & \multirow[t]{2}{*}{ OR $95 \% \mathrm{CI}$} & \multirow[t]{2}{*}{$P$ Value } \\
\hline & \multicolumn{2}{|c|}{ Underweight } & \multicolumn{2}{|c|}{ Normal } & & \\
\hline \multicolumn{7}{|c|}{ Pendapatan Keluarga } \\
\hline Tinggi & 17 & 30,9 & 38 & 69,1 & \multirow{3}{*}{$\begin{array}{c}4,997 \\
(2,225-11,218)\end{array}$} & \multirow{3}{*}{0,000} \\
\hline Rendah & 38 & 69,1 & 17 & 30,9 & & \\
\hline Total & 55 & 100 & 55 & 100 & & \\
\hline \multicolumn{7}{|l|}{ Pola Makan } \\
\hline Baik & 37 & 67,3 & 50 & $\overline{90,9}$ & \multirow{3}{*}{$\begin{array}{c}4,865 \\
(1,655-14,299)\end{array}$} & \multirow[t]{3}{*}{0,005} \\
\hline Kurang & 18 & 32,7 & 5 & 9,1 & & \\
\hline Total & 55 & 100 & 55 & 100 & & \\
\hline
\end{tabular}

Responden dengan pendapatan keluarga rendah lebih banyak pada kelompok balita underweight $(69,1 \%)$ daripada kelompok balita normal $(30,9 \%)$. Hasil uji ChiSquare menunjukkan ada hubungan bermakna antara penghasilan keluarga dengan kejadian balita underweight $(p=0,000)$.

Responden dengan pola makan kurang lebih banyak pada kelompok balita balita underweight $(32,7 \%)$ daripada kelompok normal $(9,1 \%)$. Hasil uji Chi-Square menunjukkan ada hubungan bermakna antara pola makan kurang pada balita dengan kejadian balita underweight $(p=0,005)$.

\section{PEMBAHASAN}

\section{Hubungan Pendapatan Keluarga dengan Kejadian Balita Underweight}

Responden dengan pendapatan keluarga rendah lebih banyak pada kelompok balita underweight $(69,1 \%)$ daripada kelompok balita normal $(30,9 \%)$. Hasil uji ChiSquare menunjukkan ada hubungan bermakna antara penghasilan keluarga dengan kejadian balita underweight $(\mathrm{p}=0,000)$. Hasil perhitungan OR menunjukkan responden dengan pendapatan keluarga rendah 4,997 kali untuk mengalami kejadian balita underweight dibandingkan dengan keluarga dengan pendapatan tinggi $(95 \% \mathrm{Cl} 2,225-11,218)$.

Hasil penelitian ini sejalan dengan penelitian Kurnia Wardhani, et al (2019) yang menunjukkan bahwa pendapatan keluarga yang tinggi sebagian besar $66,7 \%$ memiliki balita yang status gizinya tidak bermasalah sedangkan pendapatan keluarga yang rendah sebagian besar $58,6 \%$ memiliki balita yang status gizinya bermasalah. Hasil uji Chi-Square menunjukkan nilai $p$-value $=0,005(p<0,05)$ yang berarti bahwa pendapatan keluarga memiliki hubungan dengan status gizi balita (Kurnia Wardhani et al., 2019).

Penelitian Panda, Basant Kumar et all (2020) di India juga menunjukkan bahwa keluarga dalam kategori sangat miskin dari indeks kekayaan meningkatkan prevalensi terjadinya balita underweight dibandingkan dengan anak-anak dari keluarga yang berpendapatan tinggi, dikertahui terdapat $54,76 \%$ anak underweight dari keluarga sangat miskin dan $53,46 \%$ anak underweight dari keluarga miskin (Syahrul et al., 2016).

Penelitian Siddiqui, et al. (2020) menunjukkan bahwa pendapatan keluarga 
menjadi faktor penentu kejadian malnutrisi dalam keluarga. Keluarga dengan pendapatan rendah / miskin berpotensi mengalami kekurangan gizi dan kurang optimal melakukan pemeliharaan kesehatan balita. Kemiskinan dalam keluarga dapat memperburuk kejadian malnutrisi, orang tua cenderung hanya memperhatikan pemenuhan rasa lapar dengan memberikan konsumsi makanan pokok murah dan berenergi tinggi seperti karbohidrat dan lemak saja tanpa memperhatikan kualitas makanan bernutrisi bagi balita dan keluarganya (Siddiqui et al., 2020).

\section{Hubungan Pola Makan dengan Kejadian Balita Underweight}

Responden dengan pola makan kurang lebih banyak pada kelompok balita balita underweight $(32,7 \%)$ daripada kelompok normal $(9,1 \%)$. Hasil uji Chi-Square menunjukkan ada hubungan bermakna antara pola makan kurang pada balita dengan kejadian balita underweight $(p=0,005)$. Hasil perhitungan OR menunjukkan responden dengan pendapatan keluarga rendah 4,865 kali untuk mengalami kejadian balita underweight dibandingkan dengan keluarga dengan pendapatan tinggi (95\% Cl 1,655-14,299).

Hasil penelitian ini sejalan dengan penelitian Sambo, Mary et all (2019) mengenai analisis hubungan pola makan dengan status gizi pada anak usia prasekolah di TK Kristen Tunas Rama Kota Makassar, didapatkan bahwa dari 78 responden yang diteliti terdapat $64(82,1 \%)$ responden dengan kategori pola makan baik dengan status gizi kategori baik. Hasil uji Chi Square diperoleh nilai $\rho=0,015$, dengan demikian ada hubungan antara pola makan dengan status gizi pada anak usia prasekolah di TK Kristen Tunas Rama Kota Makassar (Sambo et al., 2020).

Pola makan merupakan gambaran mengenai macam, jumlah, dan komposisi bahan makanan yang dimakan tiap hari oleh satu orang yang merupakan ciri khas dari suatu kelompok masyarakat tertentu. Pola makan yang terbentuk sangat erat kaitannya dengan kebiasaan makan seseorang. Mengkonsumsi makanan yang baik akan memungkinkan untuk mencapai kondisi kesehatan dan kondisi gizi yang baik. Orang tua yang menyadari betapa pentingnya kesehatan dalam keluarga akan mengajarkan kebiasaan makan yang baik pada anak dengan pola makan yang teratur $3 x$ sehari dan selalu memperhatikan kandungan gizinya yang mengacu pada gizi seimbang (Sambo et al., 2020).

Konsumsi bahan makanan perlu menunjukkan adanya keanekaragaman. Hal ini sangat baik karena tidak ada satupun jenis makanan yang mengandung semua jenis zat gizi. Oleh karena itu balita sangat perlu mengonsumsi aneka ragam makanan, jika kekurangan salah satu zat gizi tertentu pada satu jenis makanan maka akan didapati pada jenis makanan yang lainnya. Mengonsumsi beranekaragam makanan akan menjamin terpenuhinya nutrisi seimbang (Girma et al., 2019).

Hasil penelitian Prasodjo, et all (2017) mengenai pola pemberian makan pada balita underweight di Jawa Barat menunjukkan anak di wilayah dataran rendah lebih sering mengonsumsi karbohidrat untuk memastikan anak-anak makan $(r=0,28, p=0,01)$, lebih sering membiarkan anak memilih makanan yang disukai $(r=0,21, p=0,03)$ dan kurang sering memantau pilihan makanan menurut kesehatan $(r=-0,20, p=0,05)$, yaitu tidak menyesuaikan jenis makanan yang biasa dikonsumsi dengan makanan yang dianggap sehat. Selain itu, anak lebih sering jajan tanpa memantau kandungan nutrisi pada makanan $(r=-0,27, p=0,01)$ dan anakanak makan lebih sedikit protein nabati yang berasal dari kacang-kacangan. Penelitian ini juga mengkaji hubungan antara rata-rata frekuensi konsumsi jenis makanan (Consumption practice) dengan status gizi anak. Penelitian 
menunjukkan bahwa status gizi balita berkorelasi signifikan dengan pilihan makanan mereka di masyarakat dataran rendah. Pada masyarakat dataran rendah, anak yang semakin banyak mengkonsumsi karbohidrat $(r=-0,17, p=$ $0,09)$ dan makanan jajanan $(r=-0,17, p=0,1)$ cenderung memiliki status gizi buruk (Prasodjo et al., 2017).

Berdasarkan hasil penelitian semua anak balita mengkonsumsi makan pokok berupa nasi dengan frekuensi selalu. Hal ini dikarenakan pada saat makan pagi ratarata balita konsumsi nasi. Konsumsi siang dan malam balita juga mengkonsumsi nasi sebagai makanan pokok, hal ini karena nasi adalah makanan utama dalam mengkonsumsi sehari-hari. Hasil penelitian rata-rata balita sering mengkonsumsi sayuran, sayuran yang sering dikonsumsi yaitu berupa sayur sop, bayam, daun singkong dan kangkung. Sayuran yang paling selalu dikonsumsi anak balita berupa sayur sop dan untuk jenis buah-buahan yang sering dikonsumsi yaitu pisang dan jeruk. Konsumsi sayuran dan buah tidak selalu ada setiap hari dengan alasan rendahnya pendapatan keluarga dan anak-anak yang kurang menyukai konsumsi sayur dan buah.

\section{SIMPULAN DAN SARAN}

Berdasarkan uraian di atas dapat disimpulkan bahwa ada hubungan antara pendapatan keluarga dan pola makan balita dengan kejadian underweight. Diharapkan pemerintah mendorong masyarakat untuk memanfaatkan sumber daya alam disekitar untuk meningkatkan income perkapita masyarakat di desa Taban melalui upaya upaya pertanian, peningkatan usaha peternakan dan atau meningkatkan kondisi desa pada peningkatan usaha home industry sehingga dapat mengungkit daya beli bahan makanan bergizi dan konsumsi pangan yang berkualitas.

Diharapkan Program Peningkatan Gizi Anak melalui kerajsama lintas sektoral bersama BKKBN dan Dinas Kesehatan dapat membantu masyarakat agar dapat hidup lebih produktif baik melalui kegiatan Bina Desa, Pembinaan Kader, Pengembangan Peran dan Fungsi Posyandu dalam penanganan malnutrisi pada balita.

\section{DAFTAR PUSTAKA}

Girma, A., Woldie, H., Mekonnen, F. A., Gonete, K. A., \& Sisay, M. (2019). Undernutrition and associated factors among urban children aged 24-59 months in Northwest Ethiopia: A community based cross sectional study. BMC Pediatrics, 19(1), 1-11. https://doi.org/10.1186/s12887-019-1595-3

Kurnia Wardhani, F. M., Utami, S., \& Puspitasari, D. (2019). Hubungan Pola Pemberian Makan, Sosial Ekonomi Dan Riwayat Bblr Terhadap Status Gizi Balita. Indonesian Midwifery and Health Sciences Journal, 3(4), 349. https://doi.org/10.20473/imhsj.v3i4.2019.349-358

Prasodjo, N. W., Pandjaitan, N. K., Kinseng, R., \& Khomsan, A. (2017). Food choice practices among underweight and normal-weight children under five years of age in West Java, Indonesia. Pakistan Journal of Nutrition, 16(8), 588-598. https://doi.org/10.3923/pjn.2017.588.598 
Sambo, M., Ciuantasari, F., Maria, G., Tinggi, S., Kesehatan, I., Makssar, S. M., \& Info, A. (2020). Hubungan Pola Makan Dengan Status Gizi Pada Anak Usia Prasekolah Correlation between Dietary Habits and Nutritional Status of Preschool Childern. Jurnal IImiah Kesehatan Sandi Husada, 11(1), 423-429. https://doi.org/10.35816/jiskh.v10i2.316

Samino, F, C. A., \& Atmasari, S. (2020). Faktor Underweight pada balita 24-59 Bulan di Wilayah Kerja Puskesmas Ambarawa Kabupaten Pringsewu. Dunia Kesmas, 9(1).

Siddiqui, F., Salam, R. A., Lassi, Z. S., \& Das, J. K. (2020). The Intertwined Relationship Between Malnutrition and Poverty. Frontiers in Public Health, 8(August), 1-5. https://doi.org/10.3389/fpubh.2020.00453

Syahrul, S., Kimura, R., Tsuda, A., Susanto, T., Saito, R., \& Ahmad, F. (2016). Prevalence of underweight and overweight among school-aged children and it's association with children's sociodemographic and lifestyle in Indonesia. International Journal of Nursing Sciences, 3(2), 169-177. https://doi.org/10.1016/j.ijnss.2016.04.004

Thamaria, N. (2017). Penilaian Status Gizi. Pusat Pendidikan Sumber Daya Manusia Kesehatan, Kemenkes: Jakarta.

Unicef. (2018). Early Chilhood Development in the UNICEF Strategic Plan 2018 2021.

Watson, F., Minarto, Sukotjo, S., \& Rah, J. H. (2019). Pembangunan Gizi di Indonesia. Direktorat Kesehatan dan Gizi Masyarakat, Bapennas.

WHO. (2020). Children: improving survival and well-being. WHO. https://www.who.int/news-room/fact-sheets/detail/children-reducing-mortality

WHO, U. (2009). Child growth standards and the identification of severe acute malnutrition in infants and children.

WHO, U., \& Bank, W. (2019). Levels and trends in child malnutrition. 